\title{
THE ROLES OF POLICE SPECIAL BRANCH IN ELIMINATING THE COMMUNIST INSURGENCY 1948-1960: AN ANALYSIS
}

\author{
Amer Fawwaz Mohamad Yasid \\ Azrul Azlan Abdul Rahman
}

\begin{abstract}
Malaysia was one of the countries that have faced with security threat of Communist Insurgency inflicted by the Communist Party of Malaya (CPM) since 1948 to 1960. As after the end of World War Two, most of the countries in the region of South East Asia were infested with communist guerilla insurgencies. Meanwhile the CPM launched their armed revolt at the beginning of 16 Jun 1948, in the name of war on liberation and anti-imperialist struggles towards against the British Government Administration in Malaya. The success of the Malayan Security Forces with the guidance of British Military Forces (BMF) during the Malayan Emergency 19481960, was based on careful implementation of the Intelligence Services executed by the Malayan Police Special Branch (SB) Division, known for their high reputation and efficiency in counter-intelligence details in defeating the CPM armed insurrection. This study will focus, dissect and extract the roles and functions of the Police SB, primarily on its intelligence strategies and tactics in defeating the CPM movement, and the outcomes of the efficiency of the SB that led to the defeat of the $C P M$ during the Emergency period.
\end{abstract}

\section{Introduction}

The establishment of the SB marked the turning point for the British counterinsurgency campaign and doctrines in the Malayan Emergency. Although it was formed in 1948, it was inherited from the Malayan Security Service (MSS), which was founded in the early 1930's. However the SB only established officially in 1948 as the First Emergency began, where the British Military Forces (BMF) realized that they need an intelligence agency that effectively against the Communist insurgency in Malaya. Until that time, the SB was a secret organization, far from the knowledge of the public. Majority of the Malaysian citizen believed that the roles and functions of the SB were mainly to detain or arrest the leftist political figure in the country.

This was the public's assumption for the past two decades. In the late 1980's and 1990's, there was a major political conflict, during which, a massive number of Malaysian political figures were arrested by the SB. These incident had changed the public perceptions regarding the main role of the SB. The SB seemed to focus only on political detention or prevention measures. However, the SB had a significant responsibility in protecting and defending the internal security of the country from any subversive revolutionary movement, since the beginning of the First Emergency. Therefore, this chapter will explain the roles and functions of the SB, in eliminating the CPM, during the First Malayan Emergency, based on several tactics, and strategies, that were emphasized by the Forces, in order to defend Malaya, from the CPM's revolutionary armed struggle that had taken place for almost 12 years. 


\section{The Roles and Functions of the Police SB in the First Emergency}

The Malayan Emergency was declared, unexpectedly, in 1948, by the British. During the earlier part of the Emergency, the SB was seen as weak and unprepared for the CPM armed insurrection. Leon Comber described the organization as unprepared and slow in providing intelligence activities for the purposes of the military and security benefits in Malaya. ${ }^{1}$ In addition, Anthony Short also described the SB's unpreparedness during the early stages of the First Emergency as "the picture from the SB intelligence had too much fuzz as the intelligence information on the ground was low grade, unreliable, and probably stale that it was becoming clearer nothing did so much to find the whole conceptual of the battle itself". 2

Thus, one of the main roles of the SB was to supply the Army and the Malayan Security Forces (MSF) with good qualities of intelligence. This was highlighted by Former Deputy Superintendent (DSP), Chan Kok Kong, when he described the SB's role as "a simple structure of organization that emphasised on the intelligence data collection on the ground against the CPM underground movement inside the jungle from 1948 to 1955 respectively". ${ }^{3}$ In fact, as the Emergency proceeded, the flooding of captured Communist documents and other written materials found on their captured agents and from communist jungle base camps had enlightened the organizational task of the SB in decoding the enemy's secret messages, directives letter and orders. All these were advantageous to the collection of valuable intelligence that can be used against the enemy as these messages. ${ }^{4}$ If examined closely, the evidences could disclose the exact location of the Communist guerrillas movement, the location of jungle bases, the food dump, and, the meeting places. In certain circumstances, it could also reveal how the Communist secret underground communication was operated, as well as, their intentions and plans. ${ }^{5}$

The importance of the captured documents of the enemy, was well described by Former Superintendent Stephen Gonzago, a former SB field operative who served in the war against the CPM since First Emergency. Gonzago claimed that "these documents or whatever written materials found on the field will be kept securely by the SB because within the SB department, they had formed a unit comprising of officers who were well trained in Chinese dialects and will be assigned with the task to interpret the captured enemy documents". ${ }^{6}$ The captured documents will be filed by the SB Chinese officers. The first step was to pass the documents to the SB's interpreter team. These documents contained a lot of information, such as, the location of the enemy and hidden food dumps. ${ }^{7}$ There may also be intelligence information, for instance, the CPM ambush planning, future sabotage intention, the number of strength of CPM Assault Units, locations of meeting places and the names of Communist logistics suppliers and collectors (Min Yuen) - all the information which could help the SB to neutralize the enemy greatly. ${ }^{8}$

However, the SB faced difficulties when it came to translating secret documents and messages, obtained from captured or dead enemies, due to the insufficient amount of translators, particularly Chinese translators, as in most cases, the written materials of the enemy were in Chinese. ${ }^{9}$ In order to tackle this problem, the SB came up with a solution: by working closely with the Psychological Warfare Department, and, acknowledging their capability to translate the captured documents of the enemy, since they had a number of good Chinese translators working under the department. ${ }^{10}$

Besides having insufficient Chinese translators, the SB also faced problem in acquiring sufficient Chinese personnel. ${ }^{11}$ This happened during the early Emergency, 
when the SB was not prepared in becoming the main organization and being in charge of intelligence data collection for the MSF and BMF. The major factor that contributed to the insufficient number of Chinese personnel, in the SB organization, was the Malayan Emergency. This period was known as the period of ethnicity clash between the Malay and the Chinese, since the SF was dominated by the Malays, especially, the Police Forces. In contrast to this, the CPM movement was mostlyChinese dominated, and, majority of its members were strong supporters of Mao Tse Tung. ${ }^{12}$

The Chinese community members in Malaya did not agree with the CPM's atrocities in terrorising Malaysia with their armed insurrections. The number of the Chinese SB officer was scarce even after four years of the SB's establishment. ${ }^{13}$ In reality, to create an effective intelligence organization required perfect plans and an adequate time of implementation of the intelligence training. ${ }^{14}$ To establish good quality intelligence organization was a hard task, and, it required, at least, two to three years, before the intelligence organization can become fully-fledge, effective and operational. ${ }^{15}$ Inevitably, there will be insufficient capabilities, as shown by the SB, in the early Emergency. Even though the SB operated with weak conditions, it was clear that they were successful as the first intelligence body, in the First Emergency. The main role of the SB in the First Emergency was to eliminate the CPM Min Yuen Organization. ${ }^{16}$ This was the most important objective of the SB, as Min Yuen, was a secret underground organization, built by the CPM, in order to supply their forces, with basic necessities, such as, food, medicine, ammunition, armament and intelligence. ${ }^{17}$

Difficulties faced by the SB in locating Min Yuen became evident when the organization started to operate secretly within the society. ${ }^{18}$ This meant that anybody could become the CPM Min Yuen agents, for, they lived like the public, and blended well with the society. ${ }^{19}$ They might be farmers, rubber tappers, villagers, traders, and even small hawkers. ${ }^{20}$ The major concerned of the SB on these Min Yuen agents was their roles in providing intelligence on the SF movements. ${ }^{21}$ By dressing up as farmers or rubber tappers, the Min Yuen agents, might send information, regarding the movement of the Security Forces (SF) in the operational area. At the same time, the Min Yuen had their own method of communicating between the organization and their members. ${ }^{22}$ They did not use wireless radio, even though, they had had them since the World War Two, because it will be easy for the SF, to locate their position, through the transmission of radio waves, which carried their messages and broadcast. It might also be possible for the SF to listen to, and, figure out their secret codes and revealed their plan and intentions. ${ }^{23}$ For these reasons, the Min Yuen used a secret communication method, through their Personal Carrier. ${ }^{24}$

Personal Carriers were communist agents entrusted by the organization to carry out and deliver secret directives letters to their main base, jungle base, and unit's commander. However, not every member can be personal carriers for the Min Yuen organization. Only those who were fully trusted, by the High Command CPM leaders, will be selected for the job. ${ }^{25}$ If necessary, they will be left to die, as their main task was to deliver, and, protect the security of the secret messages and directives, at all cause, from falling into the hands of the SF. According to intelligence resources, the secret directives letters normally contained instructions from senior commanders of the CPM, to implement future plans, such as, assault and ambushes on the jungle patrols of MSF, sabotage and espionage activities, as well as, other activities that were considered as important to the CPM movements in the country. ${ }^{26}$ 
Normally these messages will be written in Chinese using secret codes and Chinese terms that can be very hard to understand, unless, the reader himself, is a communist. ${ }^{27}$ The method of using jungle courier to deliver messages can be executed using variety of ways. On certain occasions, messages will be rolled into tiny slips and hidden in places that were unexpected by the SF, particularly, when the courier was searched at security roadblocks and checkpoints. ${ }^{28}$ Among the most popular method was to put the rolled slips into bicycle handle grips, or, in the sleeves of the trousers, or dress, that were properly sealed. The secret directive letters will then be delivered directly to the right person, or, by leaving it in a secure place and will be picked up later. ${ }^{29}$

The main reason that the CPM used rolled slips was to avoid the exploitation of information by the SB, if, the Communist jungle courier was captured by the SF. The rolled slips contained information on communication, often, linked from one CPM Assault Units, to another, and were vital information. In order to ensure that their communication security system was protected, from time to time, rolled slips were used to avoid the leakage of the CPM intelligence. ${ }^{30}$ This was, by far, the toughest task, faced by the SB, particularly, in locating the secret directive letters. Despite all these, in certain cases, the SB managed to capture Min Yuen jungle couriers. This was a blow to the CPM, as the courier might be manipulated and forced by the SF to disclose their main jungle base, and, underground organization, during the interrogation process conducted by the SB. ${ }^{31}$ This was one of the advantages of the Min Yuen communication system, for, once their jungle courier were captured or killed, their organization will be in danger, as the SB can use the information contained in the directive letters, to fight against the CPM movement.

This was highlighted by Meor Roslan bin Meor Jaafar, a former Assistant Superintendent of Police (ASP), and, a former SB operative. The rolled slips, or, secret directive letters that were confiscated by the SB, were then used against the CPM's main command. For instance, if the message decoded by the SB Chinese translators was "RENDEZVOUS AT IPOH ON 15 OCTOBER 1952 AT 10.00 P.M.", the SB will use this information to direct the CPM guerrillas into a trap. The SB, with the coordination of the MSF jungle squadron, will conduct an ambush and surround the meeting points of the CPM insurgents. The Communist were expected to trust these messages to be true as the courier will be put back at the secret location that had been set up by the CPM guerrillas, but, without the knowledge that these messages had been leaked to the SF. ${ }^{32}$ This showed how the MSF was successful in penetrating the Min Yuen movement, during the First Emergency, with the help from the SB, using counter-intelligence methods.

The formation of the SB, under the instructions of the British Military Forces (BMF), was the most appropriate idea, conducted at the most appropriate time, in order to defeat the CPM armed insurrection in Malaya, during the First Emergency campaign. A lot of historians and academicians in the strategic and insurgency studies accredited the significance of the roles and function of the $\mathrm{SB}$, in providing a successful result on the MSF, and, the BMF, in the war against the insurgency in Malaya, such as, Comber, ${ }^{33}$ R. W. Komer, ${ }^{34}$ Anthony Short, ${ }^{35}$ Leong Chee Woh, ${ }^{36}$ and Reduan Haji Asli. ${ }^{37}$

The SB highlighted the roles of the intelligence, and, was successful in making the CPM vulnerable to the tactics that were carried out by the MSF. After years of conflicts in the First Emergency, the SB had shown and proven that intelligence was the key to a successful conclusion in Malaya. It was the most effective weapon to hunt down and combat the CPM, until the late 1960, when the Emergency was revoked, 
and, the CPM retreated to the Southern Thailand, to revive their armed struggle, since the First Emergency became the CPM's first "Major blow" among other losses throughout the 12 years of campaign.

\section{Tactics and Strategies Emphasized by the SB in Defeating the CPM}

According to the British Intelligence, there were 8 main sources of intelligence: the Surrendered Enemy Personnel (SEP), the Captured Enemy Personnel (CEP), the captured enemy documents, the identification of the dead Communist, the information supplied by agents and informer, and, by the general public, ${ }^{38}$ the reports by the SF patrols, the visual air reconnaissance, and, Air photography, and interpretation. ${ }^{39}$ These intelligence sources were mainly used for the purpose of locating the enemy's base camps that were hidden in the jungle.

However, we must understand that the task of locating the enemy's base camps, was a tough job, even, when the SF had already obtained sufficient intelligence. The reason for this was the intelligence would not necessarily point the exact locations of the CPM jungle base camps, since the enemy's base camps will be moved, from time to time, depending on the security level situations, from one place, to another sector, or, another safe area. ${ }^{40}$ In the early campaign, it was decided that the task of collecting intelligence sources should be done by the police, rather than, by the army. Police intelligence under the Security Branch would provide information, and, details about where the Communist base camps were located to the army, or, the combat patrol units. ${ }^{41}$

Through various deployment and execution of jungle search and destroy operation, the government had an overall plan on how they intended to disperse their manpower, which were to be allocated properly, based on military organization needs and task. This is where framework deployment existed and needed to be followed as guidelines. ${ }^{42}$ To understand the concept of Framework Deployment, Mans highlighted that "framework deployment evolved around the infantry company. A battalion normally covered a district, with its companies occupying definite sectors in the district. Sometimes it was possible to keep one company as a reserve for unforeseen circumstances, but usually under the normal circumstances, district was so large that reserves could be kept only at higher levels of command". ${ }^{43}$ The important thing was to have the troops on the ground, where they could take immediate advantage of SB information.

At the same time, Mans mentioned that the success on jungle warfare operations in hunting down the CPM guerrilla's base depended on the accuracy of the intelligence on the enemy. That was the main priority for every military commander to secure a reliable, trustworthy, and accurate intelligence information. ${ }^{44}$ This was when the SB had a bigger responsibility in providing adequate intelligence, as requested, by the MSF. Apart from providing adequate supplies of intelligence for the MSF jungle operations, the main concern of the SB was to defeat the CPM underground secret organizations. Basically, the Communist insurgents had a powerful support force in the form of civilian branch of the Communist subversive organization, known as the "People's Movement" or also known as the famous "Min Yuen". 45

In the peak years of the campaign, the Min Yuen maintained essential supply lines to the Communist guerrillas, as well as, providing recruits and intelligence service. The Min Yuen's principal weapons were terror and intimidation, with which 
they controlled the so- called "Massed Organization" which kept them supplied with food, clothing, money and medical supplies. ${ }^{46}$ However, by 1952, the position of the Min Yuen increasingly became precarious, as the Security Forces began to get a measure of them. In the mid-1950s, most of them had changed to active terrorist operations. ${ }^{47}$ When deep jungle operations were initiated by the SF, the local intelligence on the ground would conduct constant harassment on the enemy's position and clear the jungle, before the SB made an ambush. ${ }^{48}$

\section{Manipulation of the Surrendered Enemy Personnel (SEP) and Captured Enemy Personnel (CEP)}

A Surrendered Enemy Personnel, henceforth, known as the SEP, was a member of the Communist organization, or, Communist sympathizer, that was handed over to the SF or SB operatives, during the search and destroy operations. Most of the SEPs surrendered to the SF, due to several factors or reasons, such as, poor living conditions and environment: starvation, morally neglected, afraid of death, and psychological duress. ${ }^{49}$ Besides that, other factors that contributed to their surrender, included, "defection to their former organization, the temptation to the government official pecuniary rewards, as well as, intention to Self-Renewed and getting back to their society". 50

A surrendered, or, captured SEP, or CEP, was considered as the most valuable asset to the SB, and, to the events of the First Emergency. The top priority of the SB was to capture the enemies alive as they will be useful in leading to tonnes of valuable intelligence information. At the same time, the SB always stressed on their officers to put the lives of the enemy as their top priority even when conducting the intelligence gathering task. ${ }^{51}$ Several measures needed to be taken before manipulating the SEP and CEP. First of all, maintaining secrecy: in fact, the general rule was to detain the surrendered enemy, without notifying the public for as long as possible. This could become an advantage for the SB because they might use the SEP, to penetrate the CPM organization, since the enemy did not know that one of their members had been persuaded by the SB. The SB officers will determine whether or not the SEPs will be used in operations, as the SEP must not be used on immediate follow-up operations. ${ }^{52}$

The second rule was handling. Handling was also known as an interrogation process. ${ }^{53}$ Interrogation process was a vital step for the SB, as the main focus, was to extract intelligence information on the SEP's former organization. The information given by the SEP were "questionable, especially in terms of the accuracy of the stories told to the SB officers who were in charge of the interrogation process". 54 Normally, the SEP and the CEP, were interrogated by Chinese SB operatives, since the CPM members were mainly Chinese and used Chinese to communicate with others. Interrogation process held significant objectives for the SB. One of the objectives was for the SB interrogator to gain the trust of the SEP/CEP as they had been indoctrinated by the Communist's radical ideologies for almost all of their lives. In order to gain the enemy's trust, "the SB officers will approach the enemy with good manners, and, as politely as possible, with the purpose of winning the hearts and minds of the SEP, since, this might be an effective way to build up their trust in the SB interrogators. The interrogation process generally takes about 7-14 days, depending on how well the SEP cooperated with the SB". 55

The accuracy of the information, given by the SEP and CEP, depended on how well they cooperated during the interrogation process. The interrogation process 
was an art that needed various talents and brainwashing skills. It required superb psychological skills, in order to turn the SEP to the government's side. The process might take days, weeks, or even months. The procedures of handling the CEP and the SEP were both the same. The CEP member was put in operations, within the period of 72 hours, after his capture, to ensure that the secrecy of the information, obtained by the CEP, was still relevant before it was discovered by the other members that he was detained by the SB. ${ }^{56}$

During the interrogation process, questions will be conducted based on the position of the members in the force (enemy), and, the roles that they take in the former organization. If the captured member was a high ranking officer, the questions will focus on his unit's strengths and activities. ${ }^{57}$ There were two sets of predetermined questions asked by the SB. Examples of the questions were: name, race, and the dialect used by the CEP/SEP, the length of time the SEP had been in the jungle, the SEP's ranks, and, units, as well as, if there were other CPM members who would want to surrender. ${ }^{58}$ If there were, the SEP needed to go back into the jungle and persuade them to surrender, or, to go back into the jungle and work for the SB/SF, instead.

Under these circumstances, if the SEP/CEP did not answer the first set of questions, the SB officers who were in charge of the interrogation process will ask the following questions, to decide how the SEP could be of use for further operations, such as: How many occupied camps does the SEP know to which he can lead the SF patrols? and are they occupied?, and how long will it take to reach them?, When does he think that his absence will be noticed?, When would the members in the camps were likely to know of his surrender?, Were there any routes likely to be used by the Communist guerrillas in coming into or leaving the camps?, and does the SEP know any kind of arms or food dumps, and, the details of the contents hidden nearby the camps?. ${ }^{59}$

These two sets of question were standard questions that were asked by the SB interrogators. Besides these questions, the SB officers were eligible to ask any questions that he thought was appropriate and could lead to the success of future SF operations. Nevertheless, the accuracy of the information given by the SEP/CEP depended on how well the CEP was willing to cooperate with the SB, as well as, how well the interrogator utilized his inter-personal skills in manipulating the enemy, by using methods that he thought were suitable. To ensure whether the SEP/CEP was telling the truth or lies, DSP Chan Kok Kong highlighted that "the SB will set up assessment teams: groups of $3-5$ person (normally SB most experienced field operatives) who will observe the interrogation process. These assessment teams will determine the accuracy of the data given by the SEP and they will also disclose any of the SEP previous subversive activities through their personal files. This was a measure to convince the SEP to give his full support and cooperation to the SB as the information stated on the personal files of the SEP will be used against the SEP in the event that he seemed to be unwilling to cooperate". ${ }^{60}$

There was no evidence to show that the SB used torture methods as some kind of approach, in extracting the information from the enemy, during the interrogation process, although, the SB officers might have intended to carry out such deplorable actions. ${ }^{61}$ However, Clutterbuck highlighted that in some cases, the SB interrogation process was conducted harshly. He mentioned that "the SB interrogation technique was much more subtle than a red-hot poker as the victim (enemy suspect) will be put in the dark on passenger seat of a parked car, and he will be interrogated with a longslow exhaustion process". ${ }^{6}$ 
An important lesson obtained from the interrogation process was how well the SB interrogator was willing to understand the enemy's way of thinking, through their behavioural patterns, mental processes, emotional responses, and psychological beliefs, ${ }^{63}$ since the SEP/CEP were the CPM's underground organization. An ordinary person would not be able to understand what they had been through before this. ${ }^{64}$ If the SEP and CEP agreed to be the informer for the government, particularly, the informer for SB, they will be sent to their former organization for intelligence gathering process, and, to infiltrate them from the inside. ${ }^{65}$ Besides that, the SEP or CEP will also work closely with other SF patrol units, and, help them to locate the CPM jungle camps, the location of Dead Letter Boxes (DLB), food dumps, arms dumps, or even identifying dead enemy for intelligence purposes. ${ }^{66}$

The SEP was suitable for the job as jungle trackers, and in certain circumstances, they will serve as the jungle tracker for the SF units in locating their fellow comrades who were well blended, and, hidden in the society or jungle environments. At the same time, the SEP or CEP will serve as the interpreter for the SB Contingent and Divisional Office. ${ }^{67}$ They might be given the task to interpret the intelligence data contained within the captured CPM documents. Most of the time, captured documents retrieved from dead enemy bodies will become the "most valuable intelligence information for the SB as it will disclose vital information on the enemy's activities, such as, locations of meeting places for the CPM High Command and State leaders, locations of the food dump and arms dump, time and places of CPM guerrillas units rendezvous points, as well as, future intention of the CPM guerrilla units' sabotage or assaults activities". ${ }^{68}$ Though, the captured documents were written in Chinese language, it was not the same as the Chinese language used in daily communication. Instead, they were written in "secret codes and messages that were only known by certain SEP or CEP who could understand and interpret the contents of the messages". ${ }^{69}$ This demonstrated that the cooperation between the $\mathrm{SEP} / \mathrm{CEP}$, and, the SF was the most important part of the war against the CPM.

\section{Establishment of Listening Post in Eliminating the CPM Movement}

Besides manipulating the SEP and CEP, the SB also used the method of establishing listening post, and, employment of SB agents and informer, to infiltrate the CPM's underground organization. Listening post was the SB's informer, and he, might have a connection with the CPM guerrillas or sympathizers. ${ }^{70}$ Their main task was identifying the movement or intention of the enemy organization. Besides that, they might be able to "locate the position of the enemy's jungle base camp, through their connections with the enemy members, as the Communist guerrillas would not notice that one of their friends was a government agent". ${ }^{71}$

There are certain criteria that were considered by the SB in selecting the person to become an agent for their listening post. The listening post will normally be a static position where the SB agents could monitor the movement of the enemy agents and their sympathizers. However, the chosen person must be "humble, and, can mix easily with their surroundings, as the only way for them to retrieve intelligence information was through verbal conversations with the locals". ${ }^{72}$ At the same time, during the First Emergency, the SB also used the blackmailing method on certain individuals who might have a link to the CPM organization, in order to force them to serve as a listening post for the SB. However, intelligence data collected through 
blackmailing method might not be genuine, as the cooperation of the source can be doubtful. ${ }^{73}$

Several strategic locations was chosen by the SB to employ the static position of their listening post. Among the popular locations were places with high public concentration, such as, village, town, main markets, restaurants, social clubs, Chinese temples and also New Village including aborigine's compound. ${ }^{74}$ Those locations were chosen, due to higher chances of the listening post to make contact with the CPM guerrilla members, as most of the time, the CPM guerrillas will be at these locations, to conduct meetings with their fellow comrades, resupply logistical needs, such as foods and medication, or even to obtain intelligence from the locals regarding with the movement of the SF in that particular area. The application of listening posts have certain advantages and disadvantages when it comes to the strategic point of view. The advantages of listening post are: easy to set up at any location, since the SB do not have to deploy their own personnel, to carry out the job, and at the same time, anyone can be suitable for the job, such as, villagers, aborigines, hawkers, traders, and even in some cases, beggars. ${ }^{75}$ Nevertheless, its disadvantages include the accuracy of the intelligence information which may be doubtful. This was due to the fact that there were several consequences that might jeopardize the accuracy of the listening post.

Based on the intelligence manuals, the information retrieved from the listening post was mainly through verbal communication and the reliability of information might be less accurate due to problems of noise: the accuracy of the information does not tally with the actual events, as the information might be based on rumours or stories created by the surrounding environment, such as gossips or prediction. ${ }^{76}$ Furthermore, there were two types of information delivery: Consciousness delivery, the situation when a person delivered information to the listening post, according to their own will, and not, under duress - a rare situation for the Communist guerrillas. ${ }^{77}$ Another type of delivery was the unconscious delivery.

In most cases, however, the information was given through unconsciousness delivery, a situation where a person revealed their secret or information, without realising that it will compromise their movement, which was an advantage to the receiver of the messages. ${ }^{78}$ For example, "a CPM member unexpectedly met his old friends at a restaurant. Without knowing that one of his friends was now the SB informer, he told them about the CPM's subversive activities. However, information obtained unconsciously were often deemed as unreliable and inaccurate, as the SB's listening post possibly, did not have a clear mental picture, of the information given by the sender". ${ }^{79}$ The SB informer should also be aware of the incomplete details of the information given by the sender.

The SB informer who worked with the SB at listening post also faced the risk of being captured or killed by the enemy. ${ }^{80}$ These informer were given a certain amount of financial rewards and reimbursement. It was, however, rather tough for them to control their expenditure, with the allowance that was given to them. In certain cases, the SB informer will spend their money beyond the supposed limits and this could make the enemy suspicious. ${ }^{81}$ Villagers would be suspicious if one can afford to buy a motorcycle or good quality clothes. This would then blow the informer's cover. If his real identity was uncovered by the enemy, the consequence could be fatal. 


\section{Conclusion}

The First Emergency had significantly showed that the SB was unprepared, weak, and poor in providing the MSF with reliable intelligence information. Despite the problems of poor equipment, organizational management, logistics, insufficient training and various other challenges, the SB have proven to be efficient since they learnt from their weaknesses and previous mistakes. The SB evolved by concentrating on the training of their officers and operatives, in order to build up the degree of quality of intelligence gathering on the field, through the formation of the SB training School in Kuala Lumpur.

Besides focusing on the training module of intelligence and counterintelligence, the SB had developed various new strategies and tactics in counterintelligence to fight against the CPM underground movement, particularly, the Min Yuen Organization. Among the strategies and tactics were the deployment of SB agents, informer, and listening post, which were scattered across the Malayan fields in order to enable the Police Forces to infiltrate the enemy's organization effectively. Nevertheless, among the key to the success of the SB during the First Emergency was the manipulation of the Surrendered Enemy Personnel and the Captured Enemy Personnel (SEP/CEP).

Most academicians and experts on counter-intelligence on Malayan Emergency such as Richard Clutterbuck, Harry Miller, and Leong Chee Woh agreed that, these were the most vital contributions and the main factors that helped the SB in neutralizing the enemy effectively. The SEP and CEP have shown a lot of progress in leading the SB throughout the process of eliminating the enemy by providing first degree quality of intelligence to the SB. However, to obtain the SEP/CEP's attention and cooperation to serve the SB were challenging, particularly, during the interrogation process, which was carried out by the SB. It required a time consuming interrogation session and high patience on behalf of the SB interrogator, in order to obtain the trust of the SEP (winning the hearts and mind of the guerrillas), so that they will agree to cooperate.

The art of interrogation was also the most important step taken by the SB to turn the Surrendered Enemy Personnel (SEP) and Captured Enemy Personnel (CEP) to their sides. The SEP and CEP also contributed a lot of cooperation in translating the captured enemy documents, which were written in secret codes and messages. Apart from their job in translating captured documents, the SEP also played vital roles as jungle trackers to locate their former jungle base locations, identifying dead enemies and locating enemy's hidden food dump in the harsh Malayan jungle. Although the SB faced greater difficulty during the First Emergency, they had proven that despite all the weaknesses and challenges, they managed to be successful in defeating the CPM insurrection, within a short period of time, considering the fact that the Communist armed insurrection posed a number of tough problems.

\section{Notes}

Leon Comber, Malaya's Secret Police 1945-1960: The Role of the Special Branch in the Malayan Emergency, Singapore: Institute of Southeast Asia Studies, 2008, p. 59.

Anthony Short, In Pursuits of Mountain Rats: The Communist Insurrection in Malaya, Singapore: Cultured Lotus, 2000, p. 359. 
An interview with DSP Chan Kok Kong, Former Special Branch Staff Officer E1A (SB Communist Underground Sections) (1951-1984) at his house in Bandar Menjalara, Kepong, Selangor, on 8 April 2016. Joining the Federation Police Force in 1951, DSP Chan was a former SB field operatives that served in the First and Second Emergency, fighting against the CPM underground movement regularly. He had served in numerous SB State Contingent Headquarters in Selangor, Perak, Terengganu, Johor, Sabah, and Sarawak before his retirement in 1984. MohdReduanHaji Aslie, Tan Sri Mohd Haniff Omar: Kepolisan dan Keselamatan, Kuala Lumpur: AMK Interaksi Sdn. Bhd., 1990, p. 177. Ibid. Anthony Short, In Pursuit of Mountain Rats, p. 363. An interview with Superintendent Stephen Kingsford Gonzago, Former SB operatives and Commander of Bukit Aman Special Branch E3M (Special Tactics and Operations) (19561992) at his house, in Bandar Utama, Petaling Jaya, Selangor, on 5 April 2016. Stephen Gonzago was the officer that captured the Central Committee Members, Chong Chor's, on 12 March 1988, at Globe Silk Store, Jalan Tuanku Abdul Rahman, Kuala Lumpur. His experience in counter-intelligence/counter-guerrilla warfare received great reputations, as he killed 6 CPM guerrillas, while serving in the SB Divisions. He was also trained by the British $22^{\text {nd }}$ Special Air Service Regiment (SAS) in 1970.

An interview with Former ASP Salleh Gomu, Former Special Branch Staff Officer E1A (SB Communist Underground Sections) (1967-1977) at his house in Wangsa Maju, Kuala Lumpur on 12 April 2016.

An interview with DSP Chan Kok Kong, Former Special Branch Staff Officer E1A (SB Communist Underground Sections) (1951-1984) at his house in Bandar Menjalara, Kepong, Selangor, on 8 April 2016.

Chew Chee To, "Psychological Warfare and Some Aspects of the Psychology of the People in Southeast Asia in Areas Where Communist Insurrection is Likely to Arise", Academic speech to the staff faculty, in the United States Amy Command, and, General Staff College, Fort Leavenworth, Kansas, USA, 15 October 1962, p. 9, Arkib Negara Malaysia. In the event of the First Emergency, the SB strongly cooperated with the Emergency Information Services Division (EIS). The EIS provided them with local Chinese translators that were capable in decoding, and, translating the captured enemy documents, which were mostly, written in Chinese secret codes and messages. Among the popular character, was the Late, Tan Sri Dr. C. C. Too, who was well known with his enthusiastic reputation, in fighting against the Communist, by leading the Psychological Warfare Division. See Lim Cheng Leng, The Story of a Psy-Warrior Tan Sri Dr. C. C. Too, Batu Caves, Selangor: LCL Publications, 2000, pp. 74-84.

According to Ching, one of the problems faced by the British government was the lack of Chinese personnel in the police force and the army, due to political reasons. Sir Gerald Templer, who was in command, came up with the implementation of the "Hearts and Mind" programmes, in order to improve the recruitment of Chinese into the Malayan forces, particularly, the police Special Branch. See Oong Hak Ching, The Chinese Politics in Malaya 1942-1955: The Dynamics of British Policy, Bangi: UKM Press, 2000, p. 180. James E. Dougherty, "They Call the Guerrilla War in Malaya" in Osanka (ed.), Modern Guerrilla Warfare: Fighting Communist Guerrilla Movements 1941-1961, New York: Free Press, 1962, p. 303. An interview with SAC Datuk Dr. Leong Chee Woh, Former Deputy Director of Royal Malaysia Police Special Branch (1981-1984), on 24 May 2015. An interview with Associate Professor, Dr. Kumar Ramakrishna, Head Centre of Excellence for National Security, S. Rajaratnam School of International Studies, Nanyang Technological University, Singapore, in his office, on 16 March, 2015. Ibid. Leon Comber, Malaya's Secret Police 1945-1960: The Role of the Special Branch in the Malayan Emergency, p. 61. Richard Clutterbuck, Riot and Revolution in Singapore and Malaya 1945-1963, London: Faber and Faber, 1963, p. 179. Mohd Reduan Haji Asli, Pemberontakan Bersenjata Komunis di Malaysia, Kuala Lumpur: Dewan Bahasa dan Pustaka, p. 30. Ibid. 
According to Tan Sri C. C. Too who was the Head of the Psychological Warfare Department, the Min Yuen agents of the Communist often mixed with the society by dressing in civilian clothes. They were put into the community, in order to manipulate the society with the Communist ideologies, and, indoctrinations. See C.C. Too's "Psychological Warfare and Some Aspects of the Psychology of the People in Southeast Asia in Areas Where Communist Insurrection is Likely to Arise".

An interview with SAC Datuk Dr. Leong Chee Woh, Former Deputy Director of Royal Malaysia Police Special Branch (1981-1984), on 24 May 2015, at 1.00 pm.

An interview with Former Assistant Superintendent Police (ASP), Meor Roslan Dato' Meor Jaafar, Former Police Special Branch operatives (1978-1984), at his office in Sungai Besi, Kuala Lumpur, on 16 November 2015.

Leong Chee Woh, Scorpio against the One-Eyed Dragon, USA: Rocky Mountain Press,1998, p. 12.

Ismail Saad, "The CPM Revolt: Why Fail?", In Khoo Kay Kim \& Adnan Haji Nawang, Darurat 1948-1960, Kuala Lumpur: Muzium Angkatan Tentera, 1984, p. 82.

Ibid. Richard Clutterbuck, Riot and Revolution in Singapore and Malaya 1945-1963, p. 180.

According to Leong Chee Woh, the Central Committee of the CPM High Command did not rely on the jungle couriers from their own units, to lead them into Thailand where the CPM Central Committee was operated. They would choose the most trusted person inside the party, and, his identity will not be revealed to the rest of the organization. Further details, see Leong Chee Woh, Scorpio against the One-Eyed Dragon, p. 17.

Leong Chee Woh, Scorpio on the Dragon Demise: The Second Malayan Communist Insurgency Emergency 1970-1990, USA: Rocky Mountain Press, 2012, p. 7.

An interview with SAC Datuk Dr. Leong Chee Woh, Former Deputy Director of Royal Malaysia Police Special Branch (1981-1984), on 24 May 2015.

Ibid.

Ibid.

An interview with Superintendent Stephen Kingsford Gonzago, Former SB field operatives, and, Commander of Bukit Aman Special Branch E3M (Special Tactics and Operations) (1956-1992), at his house, in Bandar Utama, Petaling Jaya, Selangor, on 5 April 2016.

An interview with Meor Roslan Dato'Meor Jaafar, former Assistant Superintendent Police (ASP), and, former Police Special Branch operatives (1978-1984), at his office, in Sungai Besi, Kuala Lumpur, on 16 November 2015, at $10.30 \mathrm{am}$.

Ibid.

Ibid. Leon Comber, Malaya's Secret Police 1945-1960: The Role of the Special Branch in the Malayan Emergency, p. 282.

R. W. Komer. The Malayan Emergency in Retrospect: Organization of a Successful Counterinsurgency Efforts, USA: RAND Corporation, 1975, p. 41.

Ibid. Anthony Short, The Communist Insurrection in Malaya: 1942-1948, pp. 363-364.

Leong Chee Woh, Scorpio the Communist Eraser, USA: Rocky Mountain Press, 1996, p. 32.

Ibid. Mohd Reduan Haji Asli, Pemberontakan Bersenjata Komunis di Malaysia, p. 208.

According to Clutterbuck, there are some differences between an agent and an informer, although it was assumed that they were identical. An Agent is a trusted member of the enemy organization who is willing to betray his former organization secrets and lead the Security Forces to information that might help them to win the battle for the government forces. Meanwhile, an informer is a local man recruited by the SF, to provide intelligence information of the enemy, based on what he heard and perceived. Both of the agent and informer are paid by the government with a sum of pecuniary payment, based on the intelligence information that might lead to the captivity or assassinations of the enemy members. See Richard Clutterbuck, The Long Long War: The Emergency in Malaya 1948-1960, London: Cassel, 1966, pp. 96-99.

The Conduct of Anti-Terrorist Operations in Malaya. Director of Operations, Malaya, 1958, Restricted.

Arkib Negara Malaysia, 1957/0537801 “OPERATIONS-GENERAL”, p. 15.

The Police Intelligence Security Branch, or also known as, "The Special Branch (SB)" was formed by the British Government, in 1948, under the direct command of the Malayan Security Services (MSS). The SB was under the supervision of The Malayan Federation Police. The function of the SB was to gather enemy intelligence, which were usually obtained 
from the interrogation of the surrendered and captured CPM's guerrillas. The SB units were trained personally by the British M15 Intelligence Agencies and London Metropolitan Police SB. A part of the tough training programme, the SB members were required to be able to speak Chinese, for the Malays and Indian, while the British SB officers were required to speak Malays, and vice versa. The SB unit could be defined as the front line intelligence units for the Malayan Security Forces, during the First, and, the Second Emergency. They provided many of the enemy intelligence details, such as, food dump, signs, and identifications, during the Search and Destroyed operations. The SB still exist, up until today, and were under the command of The Royal Malaysian Police (PDRM). See Leon Comber,The Malaya's Secret Police 1945-1960: The Role of The Special Branch in the Malayan Emergency, pp. 3-5.

Rowland S. Mans. "Victory in Malaya", in Greene, TheGuerrilla and How to Fight Him, USA: Frederick A. Praeger, 1967, p.123.

Ibid.

Ibid.

Min Yuen or the Peoples Movement was a mass organization, under the CPM, that move among the citizens in order to support the CPM guerrilla warfare. At the same time, the Min Yuen would support the MNLA to execute subversive activities, such as, sabotage, espionage for the gathering of the enemy intelligence, recruitment of new party members and cadres, providing continuous supplies of food and money by using act of force on the citizen, and developing and broadcasting the Communist propaganda among the Malayan society. The Min Yuen was organized by using the communist cells system and lived with the civilians without any weapons or arms. See Mohd Reduan Haji Asli, Pemberontakan Komunis di Malaysia, p. 30 and T. N. Greene, The Guerrilla and how to fight him, p. 118. Victor Purcell, Malaya: Communist or Free?, London: Victor Gollancz, 1954, p.63. Spencer F. Chapman, The Jungle is Neutral, London: Chatto andWindus, 1953, p. 30. Arkib Negara Malaysia, 1957/0537801 “OPERATIONS-GENERAL”, p. 14. See Richard Cluterbuck, The Long LongWar: The Emergency in Malaya 1948-1960, p. 104. An interview with Superintendent Stephen Kingsford Gonzago, Former SB field operatives and Commander of Bukit Aman Special Branch E3M (Special Tactics and Operations) (19561992) at his house in Bandar Utama, Petaling Jaya, Selangor on 5 April 2016. Ibid.

The Conduct of Anti-Terrorist Operations in Malaya. Director of Operations, Malaya, Chapter17, Section 3, p. 3, 1958, Restricted.

Ibid.

An interview with DSP Chan Kok Kong, Former Special Branch Staff Officer E1A (SB Communist Underground Sections) (1951-1984) in his house at Bandar Menjalara, Kepong, Selangor on 8 April 2016.

An interview with Superintendent Stephen Kingsford Gonzago, Former SB operatives and Commander of the Bukit Aman Special Branch E3M (Special Tactics and Operations) (19561992), at his house in Bandar Utama, Petaling Jaya, Selangor, on 5 April 2016.

The Conduct of Anti-Terrorist Operations in Malaya. Director of Operations, Malaya, Chapter17, Section 3, p. 4, 1958, Restricted.

An interview with DSP Chan Kok Kong, Former Special Branch Staff Officer E1A (SB Communist Underground Sections) (1951-1984), at his house, in Bandar Menjalara, Kepong, Selangor, on 8 April 2016.

The Conduct of Anti-Terrorist Operations in Malaya. Director of Operations, Malaya, Chapter17, Section 3, p. 16, 1958, Restricted.

Ibid.

An interview with DSP Chan Kok Kong, Former Special Branch Staff Officer E1A (SB Communist Underground Sections) (1951-1984) at his house, in Bandar Menjalara, Kepong, Selangor, on 8 April 2016.

An interview with Superintendent Stephen Kingsford Gonzago, Former SB operatives and Commander of Bukit Aman Special Branch E3M (Special Tactics and Operations) (19561992), at his house, in Bandar Utama, Petaling Jaya, Selangor, on 5 April 2016. Ibid. Richard Clutterbuck, The Long LongWar: The Emergency in Malaya 1948-1960, pp. 9798.

Ibid. 
Chew Chee Too, "Psychological Warfare and Some Aspects of the Psychology of the People in Southeast Asia in Areas Where Communist Insurrection is Likely to Arise".

An interview with SAC Datuk Dr. Leong Chee Woh, Former Deputy Director of Royal Malaysia Police Special Branch (1981-1984) on 24 May 2015.

Ibid. The Conduct of Anti-Terrorist Operations in Malaya. Director of Operations, Malaya, Chapter17, Section 3, p. 3, 1958, Restricted.

According to Superintendent Stephen Gonzago, once the SEP had agreed to cooperate, they will be assigned to a Special Projects Units where the SEP will play their roles to help the SB to neutralize the enemy. Hence, the main role of the SEP was to lead the SF team in locating their former organizations. This information were retrieved from the interview sessions with Superintendent Stephen Kingsford Gonzago, Former SB operatives and Commander of Bukit Aman Special Branch E3M (Special Tactics and Operations) (1956-1992) at his house, in Bandar Utama, Petaling Jaya, Selangor, on 5 April 2016.

An interview with General Tan Sri Datuk Ghazali Seth, former Malaysia Chief of Armed Forces (1981-1986) at his office in PhileoDamansara, Petaling Jaya on 17 November 2014. An interview with SAC Datuk Dr. Leong Chee Woh, Former Deputy Director of Royal Malaysia Police Special Branch (1981-1984) on 24 May 2015.

An interview with DSP Chan Kok Kong, Former Special Branch Staff Officer E1A (SB Communist Underground Sections) (1951-1984), in his house, at Bandar Menjalara, Kepong, Selangor, on 8 April 2016.

An interview with Superintendent Stephen Kingsford Gonzago, Former SB operatives and Commander of Bukit Aman Special Branch E3M (Special Tactics and Operations) (19561992), at his house, in Bandar Utama, Petaling Jaya, Selangor, on 5 April 2016.

Ibid.

Ibid.

An interview with SAC Datuk Dr. Leong Chee Woh, Former Deputy Director of Royal Malaysia Police Special Branch (1981-1984), on 24 May 2015,

An interview with Superintendent Stephen Kingsford Gonzago, Former SB operatives and Commander of Bukit Aman Special Branch E3M (Special Tactics and Operations) (19561992), at his house, in Bandar Utama, Petaling Jaya, Selangor,on 5 April 2016.

Restricted Special Intelligence Courses Manual 1970-1990, Intelligence Divisions, Department of Army, Ministry Of Defence, Kuala Lumpur. Top Secret.

Ibid.

Ibid.

An interview with SAC Datuk Dr. Leong Chee Woh, Former Deputy Director of Royal Malaysia Police Special Branch (1981-1984) on 24 May 2015.

An interview with DSP Chan Kok Kong, Former Special Branch Staff Officer E1A (SB Communist Underground Sections) (1951-1984), at his house, in Bandar Menjalara, Kepong, Selangor, on 8 April 2016.

An interview with SAC Datuk Dr. Leong Chee Woh, Former Deputy Director of Royal Malaysia Police Special Branch (1981-1984) on 24 May 2015. 